\title{
URGENSITAS UU NO. 32 TAHUN 2004 TERHADAP PILKADA SERTA IMPLIKASINYA DALAM PERUBAHAN SOSIAL KEMASYARAKATAN (Tinjauan Terhadap Pilkada NTB Tahun 2008)
}

\section{Ihsan Hamid}

Email: ihsanhamid88@gmail.com

\begin{abstract}
Artikel ini berusaha memotret perjalanan penerapan otonomi daerah di Indonesia yang telah beberapa kali mengalami perubahan, yang dipengaruhi oleh situasi perpolitikan nasional dalam rangka melakukan pemerataan kemakmuran masyarakat di Indonesia. Dilihat dari perubahan sistem otonomi daerah yang diberlakukan, perubahan yang sangat prinsip dan mendasar terjadi pada tahun 2004, saat diberlakukannya Undang-undang Nomor 32 Tahun 2004, yang memberikan kewenangan cukup besar terhadap daerah sekaligus menandakan hubungan pusat dan daerah dilakukan dengan pola desentralisasi, termasuk salah satu point penting yang menjadi amanah Undang-undang Nomor 32 Tahun 2004 tersebut adalah sistim pemilihan kepala daerah yang dilakukan secara langsung oleh rakyat yang sebelumnya dilakukan oleh DPRD provinsi untuk pemilihan Gubernur dan DPRDKabupaten/Kota untuk pemilihan Bupati/Walikota. Perubahan sistim pemilihan kepala daerah yang mendasar ini tentu menimbulkan dinamika baru ditengah sosial kemasyarakatan. Salah satunya, sangat rawan terjadinya gesekan dan konflik sosial dimasyarakat akibat adanya kompetisi ketat antar pendukung masing-masing calon yang melibatkan banyak masa. Hal ini kemudian memunculkan berbagai implikasi dan dinamika sosial kemasyarkatan yang menarik untuk dikaji dan ditelaah lebih lanjut.
\end{abstract}

Kata kunci: desentralisasi, pilkada, implikasi, dan dinamika sosial

Abstract: This article tries to document the implementation of the local autonomy in Indonensia, which experienced several overhouls affected by the political atmoshphere at the national level for the sake of the equal prosperity of the Indonesian people. Drawing on the changes on the system of the local autonomy, the most fundamental changes are the ones that occurred in 2004, during which the regulation no. 32 in 2004 was applied giving more authorities to the regions, which simultaneously marked the decentralization system, 
including the most important remark in the regulation: the application of the direct regional elections, electing the governor and regent/mayor city who were previously elected only by the regional representative house members in the local parliament. Such a fundamental change centainly brings about a new paradigm in the society. One of which is the proneness of the social riots caused by the supporters of the candidates often involving a mass of people. This generates several implications and social dynamics appealing to be researched and further investigated.

Keywords: decentralization, election, implications, and social dynamics

\section{Pendahuluan}

Tumbangnya rezim orde baru dan bergulirnya orde reformasi di Indonesia tidak saja telah membawa pergantian rezim politik tapi telah mendorong proses demokratisasi politik ke arah yang lebih luas dalam sistem politik nasional dan lokal. Setidaknya terlihat pada dua asfek yaitu mekanisme pemilihan kepala pemerintahan di tingkat nasional dan daerah serta pelaksanaan pemilihan langsung calon legislatif pusat dan daerah.

Ini dapat dilihat dari perubahan sistem pemilihan kepala pemerintahan tingkat nasional yaitu presiden dan wakil presiden yang tidak lagi dipilih oleh MPR melainkan dipilih langsung oleh rakyat. Ketentuan ini mulai berlaku setelah adanya amandemen UUD 1945 terhadap pasal 6 ayat 2 yang disahkan melalui keputusan MPR No. XI/MPR/2001 ${ }^{1}$ Sehingga pada Pemilu 2004, proses pemilihan presiden mengalami perubahan yang cukup berarti. Presiden tidak lagi dipilih oleh anggota MPR namun telah dipilih langsung oleh rakyat. Perubahan ini berarti adanya pergeseran kedaulatan politik dari parpol kepada rakyat yang secara langsung dapat memberikan suaranya dalam menentukan siapa yang mereka anggap layak untuk memimpin negara ini.

${ }^{1}$ Amande men kedua UUD 1945 pasal 6 ayat 2. 
Seiring dengan perubahan sistim pemilihan pemerintah di tingkat nasional, ternyata memiliki implikasi politis terhadap sistim pemilihan kepala pemerintahan di tingkat daerah juga, dimana kepala daerah dipilih langsung oleh rakyat pula. Namun, jika kita melihat berdasarkan pengalaman sejarah, setidaknya terdapat empat periode pemilihan kepala daerah, yaitu periode pertama, adalah periode UU No. 22/1948 dan UU No. 1/1957. Pada masa itu kepala daerah dipilih oleh DPRD Provinsi. Periode kedua, yaitu periode Penetapan Peresiden (Penpres) No. 6 UU No. 18/1956 yang lebih dikenal dengan era Dekrit Presiden, ketika diterapkan sistem demokrasi terpimpin, dan UU No. 5/1974, dikenal sebagai era Demokrasi Pancasila. Pilkada pada dua periode tersebut memiliki persamaan, yaitu calon kepala daerah dipilih oleh DPRD dan kemudian dari calon yang terpilih itu disahkan oleh Presiden. Periode ketiga, yaitu berlakunya periode UU No. 22/1999, yaitu kepala daerah masih dipilih oleh DPRD dan disahakan oleh Kemendagri. Sementara periode keempat, setelah UU 22/99 diganti dengan UU 32 tahun 2004, dimana sistem Pilkada berubah, dari tidak langsung melalui DPRD, menjadi pemilihan langsung oleh rakyat setempat dan kemudian calon yang menang disahkan dan dilantik oleh Kemendagri. $^{2}$

Dari ulasan sejarah perjalanan Pilkada tersebut maka dapat dilihat bahwa belum pernah sama sekali kepala daerah tingkat satu dan dua dipilih langsung oleh rakyat. Dengan adanya momentum pengesahan UU No. 32 Tahun 2004 yang merupakan revisi dari UU No. 22 Tahun 1999 tersebut merupakan sebuah prestasi politik dan merupakan indikasi yang menunjukkan kemajuan demokrasi. Hal ini berarti bahwa sistem pemilihan kepala daerah telah mengalami

2S.H Sarundajang, Pilkada Langsung Problematika Dan Prospek, (Jakarta: Kata Hasta Pustaka, 2005), cet I. h. 3-4 
perubahan ke arah yang lebih demokratis, dimana rakyat memiliki kedaulatan penuh atas hak politiknya dalam memilih calon pemimpin mereka. ${ }^{3}$ Sejak saat itulah maka seluruh kepala daerah di Indonesia baik tingkat satu dan dua kemudian dipilih secara langsung oleh rakyat.

Begitu juga halnya dengan NTB, sejak disahkannya UU 32 Tahun 2004 kepala daearah dipilih langsung oleh rakyat. Pada tahun 2008 provinsi NTB untuk pertama kalinya melaksanakan pemilihan gubernur sejak berdirinya. Maka pada tahun itu pula masyarakat NTB untuk pertama kalinya mendapatkan kedaulatannya secara penuh dalam menentukan kepala daerah. Namun dibalik kemajuan demokrasi tersebut, terdapat potensi lain yang dapat menimbulkan masalah baru. Pilkada langsung seringkali meninggalkan konflik elit dan kelompok di tataran elit atau masyarakat akar rumput, maka akibatnya terciptalah konflik sosial dalam masyarakat yang bisa jadi berkelanjutan sampai akhirnya menciptakan perubahan dalam tatanan sosial masyarakat yang sudah ada.

Maka jurnal yang ada dihadapan para pembaca ini, merupakan sebuah upaya untuk mencoba mendeskripsikan dan mengidentifikasi masalah Pilkada langsung khususnya di NTB dan umumnya di wilayah Indonesia lainnya dalam konteks Pilkada. Banyak harapan-harapan yang berubah menjadi kutuk dan tidak

${ }^{3}$ Lihat Phe ni Chalid, et al, Pilkada Langsung Demokratisasi Daerah dan Mitos Good Gavernance, (Jakarta: Pusat Kajian Ilmu Politik UI Be ke rjasama De ngan Partnership Kemitraan, 2005), h. 1. Ada banyak alasan me ngapa pemilihan kepala dae rah secara langsung me njadi pilihan logis saat ini. Maswadi Rauf berpe ndapat salah satunya adalah pemilihan ke pala daerah melalui DPRD ce ndrung menafikan peran rakyat dan me njadikan rakyat sebagai komoditas politik semata. Se hingga memunculkan kese njangan de ngan aspirasi rakyat dan menghasilkan ketidakpuasan. Untuk mencegah hal itu maka tidak ada pilihan lain harus melibatkan masyarakat secara langsung dalam pemilihan ke pala dae rah. Pe ndapat ini dapat dilihat dalam pe ngantar Maswadi Rauf, dalam buku yang berjudul Pilkada Langsung Demokratisasi Daerah dan Mitos Good Gavernance, h. V. 
sedikit anggapan pesimistis berubah menjadi berkah. Maka dari itu, ketidak ajegan antara realita dengan harapan yang terbentang dalam Pilkada perlu untuk didiskursuskan, juga direfleksikan. Harapannya tentu Pilkada menjadi instrumen penting bagi terwujudnya kebaikan bersama demi kemajuan bangsa.

\section{Telaah atas Tiga UU Mengenai Otonomi Daerah: Komitmen Sistem Desentralisasi Politik dan Pilkada}

Dalam sejarah perundang-undangan di Indonesia, setidaknya tercatat adanya tiga buah Undang-undang yang memiliki makna penting dalam otonomi daerah di Indonesia. ${ }^{4}$ Ketiga UU tersebut adalah UU No. 5 Tahun 1974 tentang pemerintah daerah, UU No. 22 Tahun 1999, dan UU No. 32 Tahun 2004 tentang pemerintahan daerah yang sekaligus merupakan revisi atas UU No. 22 Tahun 1999. Ketiga UU tersebut dianggap sebagai pilar penting bagi pengelolaan pemerintahan daerah yang memiliki makna politik bagi konfigurasi

${ }^{4}$ Namun sebelumnya paling tidak terdapat empat UU dan satu Penetapan Presiden mengenai kebijakan otonomi dae rah, yaitu Pertama, UU No. 1 Tahun 1945 dimana kebijakan otonomi dae rah pada masa itu lebih me nitikbe ratkan pada dekonse ntrasi se hingga kepala daerah hanyalah ke panjangan tangan pemerintah pusat. Kedua, UU No. 22 Tahun 1948 yang me nitikbe ratkan pada desentralisasi. Namun, masih ada dualisme peran, satu sisi memiliki peran besar untuk dae rah, tapi disisi lain masih menjadi alat pemerintah. Ketiga, UU No. 1 Tahun 1957 yang masih bersifat dualisme juga. Keempat, penetapan Presiden No. 6 Tahun 1959 pada masa ini kebijakan otonomi dae rah le bih menekankan dekonse ntrasi. Me lalui Perpres ini kepala dae rah diangkat ole $\mathrm{h}$ pemerintah. Kelima, UU No. 18 tahun 1965 ya ng me nitikbe ratkan juga pada dese ntralisasi de ngan memberikan otonomi yang seluas luasnya bagi daerah walaupun belum bisa le pas sepe nuhnya dari pemerintah pusat. Ini bisa dilihat dalam artikel Syahrul Hidayat, et al, Pilkada Langsung Demokratisasi Daerah dan Mitos Good Gavernance, (Jakarta: Pusat Kajian Ilmu Politik UI Bekerjasama De ngan Partnership Kemitraan, 2005), h. 28. Dan dalam tulisannya S.H Sarundajang, Pilkada Langsung Problematika Dan Prospek, (Jakarta: Kata Hasta Pustaka, 2005), cet I. h. 3-4. 
peran negara dan masyarkat. ${ }^{5}$ Ketiga UU teersebut memiliki kekhasan teersendiri dalam memaknai peran negara dan masyarakat yang bahkan terkesan saling tumpang tindih satu sama lain sehingga perlu diulas dibawah ini.

\section{Otonomi Daerah dan Komoditas Politik Orde Baru: UU No. 5 Tahun 1974}

UU No. 5 Tahun 1974 tentang pemerintahan daerah merupakan aturan legal yang menjadi acuan dalam mengatur hubungan pusat dengan daerah selama pemerintahan Orde Baru. Undang-undang itu telah berhasil membangun sebuah makna dan definisi akan otonomi daerah itu sendiri, namun kerancuan tampak jelas ketika memaknai apa yang dimaksud dengan pemerintah daerah. Kerancuan ini tampak ketika menempatkan DPRD sebagai bagian dari pemerintah daerah. Logika mengatakan ini rancu karena dalam pembagian kekuasaan politik, tidak ada lembaga legislatif yang disatukan dengan lembaga eksekutif. ${ }^{K}$ Konsekuensinya adalah, ketiadaan kontrol yang efektif terhadap eksekutif oleh legislatif dan memang itulah yang terjadi selama Orde Baru.

Ironisnya juga, UU tersebut juga sama sekali tidak menyentuh segi apapun dari sistem federasi yang memiliki kewenangan yang otonom atau semi otonom yang pada hakikatnya merupakan sistem yang membagi wilayah eksekutif dan legislatif di suatu daerah. Pasal 11 dalam pasal itu misalnya, telah menegaskan bahwa titik berat otonomi diletakkan pada daerah tingkat dua, namun pemerintah tidak mengeluarkan Peraturan Pemerintah untuk

${ }^{5}$ Lihat Syahrul Hidayat, et al, Pilkada Langsung Demokratisasi Daerah dan Mitos Good Gavernance, h. 28.

'Lihat Syahrul Hidayat, et al, Pilkada Langsung Demokratisasi Daerah dan Mitos Good Gavernance, h. 32. 
melaksanakan amanah itu. Dengan ketidak jelasan aturan main tersebut, otonomi daerah terkesan berjalan sesuai selera pejabat tinggi semata dan asas dekonsentrasi dan tugas pembantuan berjalan tidak serasi dengan asas desentralisasi. Karena itu apa yang dimaksud dengan daerah otonom dalam UU itu lebih merupakan suatu kewajiban ketimbang hak, yang mengharuskan daerah otonom untuk berpartisipasi dalam melakukan pembangunan demi kesejahteraan rakyat.

Kuatnya peran penguasa terlihat jelas dari peran yang dimiliki oleh departemen dalam negeri yang melakukan kontrol secara umum terhadap berjalannya pemerintah daerah dan gubernur disetiap daerah, sehingga persis peran DPRD dalam UU ini dikebiri sedemikian rupa. Hal ini terlihat dari pasal 22 yang mengatakan bahwa kepala daerah sebagai pemimpin sebuah daerah otonom menjalankan hak, wewenang dan kewajiban pemerintah daerah dan menurut hierarki bertanggung jawab kepada presiden melalui Mendagri. ${ }^{7}$ Jadi persis DPRD yang seharusnya sebagai lembaga legislatif yang memiliki hak penuh dalam mengawas dan mengontrol hanya diberikan keterangan pertanggung jawaban, dan terkesan tidak memiliki kekuatan apapun.

Mandulnya peran DPRD juga terlihat dari perannya yang hanya memberikan pertimbangan atas pengusulan dan pengangkatan sekretaris daerah. Dalam hal ini, mendagri dan gubernur menjadi pihak yang lebih memiliki kewenangan untuk menentukan terpilihnya seorang sekretaris daerah ketimbang DPRD, seperti terlihat dari aturan pasal 48 ayat 2 dan $3 .^{8}$ Dalam kondisi yang demikian, pada dasarnya pemerintah daerah tidak memiliki apapun yang dapat dijadikan modal untuk menjalankan sebuah

7 UU No. 5 Tahun 1974 tentang Pemerintahan Daerah, pasal 22.

8 UU No. 5 Tahun 1974 tentang Pemerintahan Daerah, pasal 48. 
daerah otonom. Pemerintah daerah hanyalan menjalankan fungsifungsi administarif semata tanpa memiliki kewengan dalam memutuskan keputusan yang bersifat stategis. Sistim dan UU inilah yang digunakan selama pemerintahan Orde Baru dalam mengatur hubungan antara pemerintah daerah dan pusat sehingga prakteknya sangat sentralistik sehingga terkesan semena-mena dan dalam teori pemerintahan lokal, apa yang dijalankan oleh pemerintah Orde Baru dengan UU No. 5 Tahun 1974 tidak menggambarkan sama sekali suatu bentuk otonomi yang dimiliki oleh suatu daerah.

\section{Percepatan Otonomi Daerah: UU No. 22 Tahun 1999.}

Berbeda halnya dengan UU di atas, UU No. 22 Tahun 1999 membawa perubahan yang cukup signifikan dalam mekanisme maupun substansi pemilihan kepala daerah. Secara prosedural, pemilihan kepala daerah dilakukan oleh DPRD, mulai dari tahap pencalonan sampai dengan penetapan. Proses pemilihan kepala daerah dilakukan melalui mekanisme pemungutan suara secara langsung dengan ketentuan one man one vote (setiap anggota DPRD dapat memberikan suara pada satu pasang calon kepala daerah dan wakil kepala daerah). ${ }^{9}$ Artinya jika sebelumnya kepala daerah hanya diajukan oleh DPRD untuk dipilih dan ditentukan oleh pemerintah, maka DPRD menurut UU N0. 22 Tahun 1999 ini memiliki kewenangan penuh untuk menentukan siapa yang berhak menjadi kepala daerah provinsi, kabupaten atau kota seperti disebutkan dalam pasal 18 mengenai tugas dan wewenang DPRD. Tidak hanya

${ }_{9}^{9}$ Lihat Dede Mariana dan Caroline Paskarina, Demokrasi dan Politik Desentralisasi, (Bandung: Puslit KP2W Lemlit UNPAD, 2007), h. 46. 
itu DPRD juga diberikan wewenang untuk meminta pertanggung jawaban gubernur, bupati atau walikota. ${ }^{10}$

Kontrol yang demikian dimungkinkan pula dengan dipisahkannya DPRD dari unsur pemerintah daerah seperti terdapat dalam UU terdahulu. Dengan adanya pemisahan ini, maka DPRD dapat menjalankan fungsinya sebagai lembaga legislatif di daerah secara efektif. Kalaupun terdapat konsultasi dengan presiden dalam pemilihan Gubernur (pasal 38), hal itu dilakukan hanya sebatas menguji apakah prosedur dan tata tertibnya sudah sesuai dengan ketentuan peraturan perundangan, bukan permohonan restu sebagaimana dahulu bisa terjadi. ${ }^{11}$

Sehingga pemerintah pusat, dalam hal ini Presiden, hanya berperan dalam pengesahan kepala daerah dan wakil kepala daerah yang telah ditetapkan oleh DPRD. Secara substansial, mekanisme semacam ini memberikan kewenangan politik yang lebih besar bagi masyarakat di daerah untuk menentukan siapa yang akan menjadi kepala daerahnya. Mekanisme pemilihan kepala daerah yang diatur dalam UU No. 22 Tahun 1999 jelas telah membawa perubahan substansial dalam proses pemilihan kepala daerah jika dibandingkan dengan sistem UU yang berlaku sebelumnya.

Namun hal ini hanya merupakan langkah awal sebab masih ada tantangan selanjutnya yakni bagaimana memperluas ruang publik dalam arti pemilihan kepala daerah harus lebih kompetitif dan ada perluasan ruang bagi masyarakat untuk mempengaruhi proses tersebut. Dalam praktiknya, mekanisme perwakilan yang diterapkan dalam proses pemilihan kepala daerah menurut UU No.

${ }^{10}$ Lihat Syahrul Hidayat, et al, Pilkada Langsung Demokratisasi Daerah dan Mitos Good Gavernance,h. 37.

${ }^{11}$ Lihat Syahrul Hidayat, et al, Pilkada Langsung Demokratisasi Daerah dan Mitos Good Gavernance,h. 37. 
22 Tahun 1999 juga mempunyai kelemahan karena memberi ruang yang sangat dominan bagi DPRD dalam proses pemilihan kepala daerah. Akibatnya, proses pemilihan kepala daerah menjadi kehilangan makna sebagai proses politik dan beralih menjadi pragmatisme politik yang dimanfaatkan oleh beberapaelit.

\section{Pilkada Langsung dan Peran Serta Masyarakat: UU No. 32 Tahun 2004}

Diawali dengan penerapan sistem pemilihan umum secara proporsional terbuka kemudian penerapan sistem pemilihan presidendan wakilnya secara langsung di tingkat nasional menjadi tonggak awal yang mengubah wajah dinamika pemilihan umum di Indonesia. Di level daerah, perubahan tersebut seolah-olah menjadi inspirasi yang memperkuat tuntutan bagi penyelenggaraan pemilihan kepala daerah dan wakilnya secara langsung. Berbagai indikasi kecurangan, praktik money politics, mobilisasi massa pendukung, serta berbagai bentuk ketidak puasan terhadap hasil pemilihan kepala daerah secara tidak langsung menjadi alasan juga merebaknya tuntutan pemilihan kepala daerah secara langsung.

Secara teoritis-normatif, tuntutan ini memperoleh dasar hukumnya dalam pasal 18 ayat 4 UUD 1945 amandemen keempat yang mensyaratkan pemilihan kepala daerah dilaksanakan secara demokratis. Pemilihan secara langsung diyakini sebagai mekanisme yang lebih demokratis dibandingkan pemilihan secara perwakilan oleh DPRD. ${ }^{12}$ Fakta menunjukkan bahwa di sejumlah daerah, pemilihan kepala daerah justru menjadi ajang pertarungan kepentingan dan pertarungan kapital antara DPRD, partai politik, dan para kandidat kepala daerah. Hal inilah yang semakin

${ }^{12}$ Lihat Dede Mariana dan Caroline Paskarina, Demokrasi dan Politik Desentralisasi, (Bandung: Puslit KP2W Lemlit UNPAD, 2007), h. 58. 
menguatkan tuntutan diselenggarakannya pemilihan kepala daerah secara langsung. Revisi UU No. 22 Tahun 1999 yang termuat dalam UU No. 32 Tahun 2004 tentang Pemerintahan Daerah menjadi landasan normatif bagi penerapan pemilihan kepala daerah secara langsung. Salah satu perubahan yang cukup signifikan ditegaskan dalam Pasal 24 ayat (5) UU 32 Tahun 2004, bahwa kepala daerah dan wakil kepala daerah dipilih dalam satu pasangan secara langsung oleh rakyat di daerah bersangkutan. ${ }^{13}$ Sehingga dengan diberlakukannya UU No. 32 Tahun 2004 persis telah merubah konfigurasi dan model politik lokal, terutama dari sistem keterwakilan menjadi sistem pemilihan langsung.

Dalam dari pada itu, Pilkada langsung merupakan salah satu langkah maju dalam mewujudkan demokrasi di level lokal. Menurut O'Neill, sebagaimana yang dikutip oleh Leo Agustino menyatakan bahwa 'all Politics is Lokal' yang dapat dimaknai sebagai demokrasi di tingkat nasional akan tumbuh berkembang dengan mapan dan dewasa apabila pada tingkat lokal nilai-nilai demokrasi berakar dengan baik terlebih dahulu. ${ }^{14}$ Maksudnya, demokrasi ditingkat nasional akan bergerak ke arah yang lebih baik apabila tatanan, instrumen dan konfigurasi kearifan serta kesantunan politik lokal lebih dahulu dibentuk atau diperhatikan. Ini artinya kebangkitan demokrasi di Indonesia-secara ideal dan aktual-diawali dengan

13 Lihat Dede Mariana dan Caroline Paskarina, Demokrasi dan Politik Desentralisasi, h. 59.

${ }^{14}$ Lihat Leo Agustino, Pilkada dan Dinamika Politik Lokal, (Yogyakarta: Pustaka Pe lajar, 2009), Cet. I, h. 17.Apa yang diutarakan ole h O'Neill di atas juga sejalan de ngan argumen yang dije laskan ole h Robert bates yang menyatakan bahwa untuk memahami lebih dalam menge nai lanskap politik-di ne gara berkembang khususnya - maka para ilmuan harus le bih memperhatikan dan mencurahkan perhatiannya pada realita politik di tingkat lokal. Ini dapat dilihat dalam bukunya Leo Agustino, Pilkada dan Dinamika Politik Lokal, h. 18. 
Pilkada langsung, sederhananya jika pondasinya sudah kuat maka sudah barang tentu selanjutnya juga akan kuat.

Jika demikian adanya, maka perubahan politik dan demokrasi dilevel nasional tidak bisa hanya dipandang hanya sebagai suatu keadaan yang membentuk dirinya sendiri tetapi berada dalam interaksinya dengan dinamika politik lokal. Mereka saling mengisi dan menaungi dalam perjalanannya. Apalagi ketika kebijakan mengenai Pilkada dilembarkan dalam lembaran negara. Sehingga Pilakada bukan hanya menjadi realitas baru bagi politik lokal di Indonesia tetapi lebih dari itu. Ia bahkan membentuk politik nasional seperti yang diutarakan oleh O’Neill.

Namun pada masa Orde Baru kondisinya sangat berbalik dari harapan itu, dimana pada masa Orde Baru politik lokal sangat dipengaruhi oleh politik di level pusat. Melalui pendekatan represifotoritarian pemerintah pusat selalu memaksakan kehendak penguasa demi kepentingan mereka di level daerah. Karena itu, dinamika politik pada saat itu tidaklah sehat. Ia bukan menjadi pondasi bagi terbangunnya demokrasi yang kuat bagi demokrasi nasional, tetapi justru ia menjadi penopang rezim otoriter. Tapi untungnya reformasi pada 1998 berhasil mengubah sebagian dari itu semua.

Oleh sebab itu, dalam konteks demokrasi lokal maka Pilkada langsung merupakan sebuah cara yang efektif untuk memberikan pendidikan politik kepada rakyat. Apalagi banyak aspek positif yang dapat diperoleh dan dicapai dalam Pilkada langsung diantaranya adalah. Pertama, kepala daerah terpilih lebih legitimit. Kedua, kepala daerah lebih memiliki tanggung jawab politik dan moral kepada masyarakat yang memilihnya langsung. Ketiga, memperkecil kemungkinan terjadinya money politic. Keempat, kepala daerah tidak mudah dijatuhkan oleh DPRD, sehingga pemerintahan 
daerah bisa lebih pasti dan stabil. Kelima, mekanisme pemilihan langsung dirasakan lebih aspiratif dan demokratis. ${ }^{15}$

\section{Hakikat Pilakada: Sebagai Pembaruan Kontrak Sosial}

Dalam negara yang menerapkan demokrasi sebagai perinsip penyelenggaraan pemerintahan, Pemilu atau Pilkada merupakan media bagi rakyat untuk menyatakan kedaulatannya. Secara ideal, Pemilu atau general election bertujaun agar terselenggara perubahan kekuasaan pemerintahan secara teratur dan damai sesuai dengan mekanisme yang dijamin oleh konstitusi. ${ }^{16}$ Dan secara teoritis normatif Komaruddin Hidayat menyatakan Pemilu atau Pilkada merupakan moment untuk menjaring wakil rakyat dan presiden serta wakilnya yang memperoleh mandat dan kepercayaan rakyat karena pertimbangan integritas dan kompetensiny. ${ }^{17}$ Dengan harapan masyarakat dapat segera mendapatkan kemakmuran dan kesejahteraan dalam hidupnya.

Dengan demikian, Pemilu atau Pilkada menjadi prasyarat dalam kehidupan bernegara dan bermasyarakat secara demokratis sehingga melalui Pemilu atau Pilkada sebenarnya rakyat sebagai pemegang kedaulatan secara tidak langsung akan: pertama, memperbarui kontrak sosial; kedua, memilih pemerintahan baru; dan ketiga, menaruh harapan baru dengan adanya pemerintahan baru. ${ }^{18}$ Tiga hal ini menjadi penting karena pada dasarnuya dan

${ }^{15}$ Ini dapat dilihat dalam bukunya H.A. Chozin Chumaidi, Etika Politik dan Esensi Demokrasi, Jejak Pemikiran Demokratisasi Politik Indonesia, (Jakarta: Pustaka Indone sia Satu, 2006), Cet II, h. 24-25.

16 Lihat Caroline Paskarina dan Dede Mariana, Demokrasi dan Politik Desentralisasi, (Yogyakarta: Graha Ilmu, 2008), h. 5

${ }^{17}$ Komaruddin Hidayat, Politik Panjat Pinang, Dimanakah Peran Agama, (Jakarta: Pe ne rbit Buku Kompas 2006), h. 56

${ }^{18}$ Caroline Paskarina dan Dede Mariana, Demokrasi dan Politik Desentralisasi, h. 
substansinya Pemilu dan Pilkada merupakan moment untuk mencoba membangun sistem dan pelaksanaan pemerintahan kedepan yang lebih baik.

Istilah kontrak umumnya kita kenal dalam ilmu hukum dan ekonomi yang mengandung makna sebagai sebuah perjanjian antara dua pihak atau lebih yang berkepentingan, dimana kedua belah pihak menyepakati sejumlah persyaratan yang mengikat pihak pihak yang mengadakan perjanjian. Dan dalam kajian ilmu politik, istilah kontrak digunakan oleh J.J. Rousseau (kontrak sosial) untuk menyebutkan konsep negara yang dilandasi perjanjian antara pemerintah dan yang diperintah atau antara rakyat dan penguasa. ${ }^{19}$ Namun, hakikat maknanya sama dengan kontrak dalam ilmu hukum maupun ilmu ekonomi, yakni adanya pihak -pihak yang bersepakat mengadakan perjanjian untuk mencapai tujuan bersama dalam sebuah ikatan yang berkekuatan secara hukum.

Sebagai suatu bentuk kontrak sosial, Pemilu atau Pilkada memuat perjanjian antara rakyat dengan mereka yang diberi mandat untuk melaksanakan kedaulatan rakyat. Kontrak ini dibuat dengan partai pemenang Pemilu sebagai bukti bahwa program-programnya sesuai dengan aspirasi rakyat. Ketika seseorang memberikan suaranya pada salah satu partai atau kandidat, maka hakikatnya suara tersebut menjadi simbol persetujuan rakyat terhadap program program partai atau kandidat yang bersangkutan. Dengan model dan harapan seperti itu rakyat secara tidak langsung memberikan pengaruh yang signifikan terhadap terlaksananya tantan demokrasi yang terbuka dan akuntabel.

Tentunya, sebagai konsekuensi dari kontrak sosial yang baru tersebut, maka akan terbentuk pemerintahan yang terdiri dari

${ }^{19}$ Caroline Paskarina dan Dede Mariana, Demokrasi dan Politik Desentralisasi, h. 
mereka yang terpilih dalam pemilu. Pemerintah baru inilah yang kemudian akan bekerja sesuai kontrak yang telah disepakati dalam pemilu. Sebagai suatu kontrak, idealnya rakyat telah mengetahui isi dari kontrak tersebut sehingga bersedia mengikatkan diri dengan pihak lainnya. Artinya setelah masyarakat melewat moment Pemilu maka masyarakat terus dituntut tetap berperan aktif dalam mengontrol dan mengawasi pemerintahan yang telah dipilih sehingga pemerintahan tersebut dapat berjalan sesuai dengan kontrak yang telah dibuat.

Oleh karena itu, transparansi selama proses Pemilu menjadi nilai prinsipil yang tidak mungkin diabaikan. Kejelasan ideologi, tujuan, program, serta cara partai politik atau kandidat melaksanakan program tersebut untuk mencapi tujuan menjadi elemen-elemen penting yang harus diketahui selama proses kampanye berlangsung.

Pergantian kekuasaan yang tercermin dari terbentuknya pemerintahan baru akan membawa harapan baru bagi rakyat, yakni harapan bahwa penyelenggaraan pemerintahan akan lebih berpihak pada rakyat sebagaimana telah disepakati dalam kontrak sosial. Karena didasari oleh suatu kontrak, maka asumsinya kedua belah pihak saling percaya sehingga terbentuknya pemerintahan baru ini akan memperoleh legitimasi 20 politik dalam bentuk kepercayaan sebagai besar rakyat. Tentu ini merupakan modal yang sangat berarti bagi pemerintah yang terpilih karena secara langsung rakyat

\footnotetext{
${ }^{20}$ Secara sederhana le gitimasi dapat diartikan sebagai sebuah pe ngakuan atau pembenaran me nurut hukum (atau Undang-undang yang berlaku); hak kekuasaan; bukti sah jati diri seseorang. Lihat Pius A Partanto dan Dahlan al Barry, Kamus Ilmiah Populer, (Surabaya: Penerbit Arloka, 1994), h. 404. Sedangkan dalam kamus besar bahasa Indonesia disebutkan bahwa legitimasi merupakan ke terangan yang me nunjukkan surat bukti diri atau ide ntitas seseorang yang sah, ke terangan ini rupanya lebih bersifat ke le gitimasi personal atau status seseorang. Lihat Kamus Besar Bahasa Indonesia, (Jakarta: PusatBahasa Depdiknas, 2008), h. 899.
} 
memberikan kepercayaan penuh terhadapnya dalam mengelola pemerintahan.

Legitimasi politik ini diperlukan selama masa pemerintahannya untuk menjalankan program -program yang telah disepakati dalam kontrak. Di sisi lain, legitimasi politik yang diperoleh akan menjadi dasar yang kuat untuk membangkitkan dukungan dan komitmen seluruh komponen negara dan masyarakat. Dengan demikian, hakikat Pemilu jauh lebih penting dibanding sekedar memberikan suara. Setiap suara yang diberikan sangat bermakna bagi terbentuknya pemerintahan baru yang legitimit, suatu pemerintahan yang dipercaya dan didukung rakyatnya. Pemilu tidak berakhir ketika seseorang sudah memberikan suaranya, tapi lebih jauh lagi, Pemilu hanyalah awal dari terbentuknya hubungan penguasa dengan pemegang kedaulatan (yakni rakyat) yang sederajat. Itu artinya rakyat dituntut untuk terus berperan aktif dalam melihat dan mengawasi pemerintah yang dia pilih sehingga pemerintahan tersebut tetap berjalan dalam rel kontrak sosialnya tersebut.

\section{Mencermati Potensi Konflik Dalam Pilkada Langsung Sebagai Bentuk Perubahan Sosial Terhadap Masyarakat}

Kita tidak dapat menutup mata bahwa konflik Pilkada mengganggu jalannya proses demokratisasi di level lokal. Aksi pengepungan dan perusakan kontor DPRD, KPU, Bupati, bentrokan dengan petugas keamanan, benturan antar pendukung calon kandidat, dan banyak lagi bentuk konflik dan kekacauan yang lainnya yang kita banyak saksikan akhir-akhir ini. Terjadinya konflik akibat dari Pilkada tersebut menunjukkan kepada kita masih lemah dan tidak dewasanya politik kita atau belum matengnya demokrasi kita. 
Padahal para pemikir politik, diantaranya Huntington serta Linz dan Stepan mengatakan, bahwa suatu negara dikatakan demokratis apabila memnuhi beberapa persyaratan yang antara lainnya adalah: pertama, memiliki kebebasan kepada masyarakat untuk merumuskan preferensi-preferensi politik mereka melalui jalurjalur perserikatan informasi dan komunikasi. Kedua, memberikan ruang berkompetisi yang sehat dan melalui cara-cara damai. Ketiga, tidak melarang siapapun berkompetisi untuk jabatan politik asalkan dia mampu dan layak. ${ }^{21}$ Dalam hal ini jelas, kompetisi politik yang damai menjadi prasyarat penting bagi tumbuh kembangnya demokrasi.

Dalam kaitannya dengan konflik Pilkada yang selama ini terjadi, maka konflik politik dan konflik Pilkada dapat dikelompokkan ke dalam konflik sosial karena di dalamnya terjadi konflik diantara anggota masyarakat sebagai akibat dari adanya hubungan dan interaksi sosial yang cukup intensif. Konflik politik biasanya berkaitan dengan masalah penguasa politik atau keputusan yang dibuatnya (keputusan politik). Masalah yang dipertentangkan dalam konflik politik berada pada tingkatan dan wilayah pelaksanaan dan penerapan. ${ }^{22}$

Tapi setidaknya, terdapat dua kriteria mendasar yang menyebabkan konflik massa diantaranya; teknis pelaksanaan Pilkada itu sendiri dan situasi masyarkat setempat dan karakteristik politik lokal.

${ }^{21}$ LihatLe o Agustino, Pilkada dan Dinamika Politik Lokal, h. 150.

22LihatAnasUrbaningrum, Ranjau-ranjau Reformasi; Potret Konflik Politik Pasca Kejatuhan Soeharto, (Jakarta: PT RajaGrafindo Persada, 1999), h. 9. 


\section{Model Konflik yang Diakibatkan Oleh Tekhnis Pelaksanaan Pilkada}

a. Penetapan Kelulusan Calon Serta Administratif di KPUD

Tahapan tersebut dapat melahirkan konflik antar massa pendukung calon kepala daerah. Apabila calon favorit dan populer di mata publik dinyatakan tidak lulus administratif oleh KPUD, serta yang nonfavorit dan nonpopulis lulus. Permasalahan ini misalnya muncul akibat adanya perbedaan penafsiran yang beragam terkait dengan syarat calon dan lain sebagainya. ${ }^{23}$

Misalnya ambil contoh klausul yang menyebutkan salah satu syarat calon pasangan kepala daerah adalah ,mengenal daerahnya dan dikenal oleh masyarakat di daerahnya' (pasal 38 ayat 1 hurup h dalam PP No. 6/2005). Tidak ada ukuran tentang apa yang dimaksud dengan kalimat,mengenal dan dikenal' itu. Apakah keliru bila kemudian ada partai politik atau masyarakat kemudian menafsirkannya sebagai ,putra daerah', sebuah istilah yang akhir-akhir ini dinilai rawan memicu konflik di beberapa daerah. ${ }^{24}$ syarat lain yang tidak jelas dan terkesan hanya lipstick semata dapat ditemukan umpamanya pada klausul yang berbunyi ,bertakwa kepada Tuhan yang Maha Esa'. Bagaimana mengukurnya karena ini bersifat abstrak sekali.

b. Kampanye

Konflik yang bersumber dari kampanye negatif antara pasangan calon kepala daerah. Berbeda dengan pemilihan

${ }^{23}$ Lihat Agus Rie wanto, Ensiklopedi Pemilu, Analisis Kritis Intropektif Pemilu2004 Menuju Agenda Pemilu2009, (Yogyakarta: el-SAB be ke rjasama de ngan Fajar Pustaka, 2007), h. 229.

${ }^{24}$ Lihat Donni Edwin, et al, Pilkada Langsung Demokratisasi Daerah dan Mitos Good Gavernance, (Jakarta: Pusat Kajian Ilmu Politik UI Be ke rjasama De ngan Partne rship Kemitraan, 2005), h. 85. 
presiden, dimana kandidat tidak terlalu lekat secara emosional maupun psikologis dengan pemilih; maka dalam Pilkada, para calon kepala daerah adalah tokoh-tokoh yang hampir pasti berdekatan-secara geografis, emosional, psikologis-dengan para pemilihnya di daerah. Sehingga, kampanye negatif yang mengarah pada munculnya fitnah mengenai integritas kandidat dukungan kelompok tertentu bisa mengundang dentuman antara massa pendukung dalam kampanye Pilkada. ${ }^{25}$ Selain itu, juga munculnya propaganda hitam antara pendukung calon untuk mempengaruhi perilaku pemilih.

Menurut Le Due Lawrence yang dikutif oleh Loe menyatkan bahwa akan muncul dua tipe blac propaganda, yakni black campaign dan negative campaign. Black campaign adalah promosi gelap yang ditujukan untuk menunjukkan kepada publik akan perilaku buruk seorang calon, sehingga calon itu dimungkinkan untuk tidak dipilih saat pemungutan suara. Dan adapun negative campaign, meski sama tujuannya dengan black campaign, namun proses propaganda itu dilakukan dengan berdasarkan pada bukti-bukti konkrit, legal dan normatif. ${ }^{26}$ Bila itu terjadi dan melibatkan elite partai politik, maka akan berpotensi terjadi amuk massa.

c. Pemungutan Suara

Proses tahapan pemungutan suara termasuk rawan untuk menjadi penyebab terjadinya konflik amuk massa. Karena biasanya dalam proses ini seringkali terjadi sebuah upaya penggiringan massa arus bawah (grassroot) kepada calon tertentu dengan cara memberikan sesuatu sebelum

${ }^{25}$ LihatLe o Agustino, Pilkada dan Dinamika Politik Lokal, h. 150-151.

${ }^{26}$ Lihat Agus Rie wanto, Ensiklopedi Pemilu, Analisis Kritis Intropektif Pemilu2004 Menuju Agenda Pemilu2009, h. 230. 
pemungutan suara terjadi dengan meminta memilih seorang calon tertentu (serangan pajar). ${ }^{27}$ Biasanya itu kadang dilakukan oleh elite parpol, elit agama, dan elit pengusaha. Dan ini biasanya rawan menyebabkan terjadinya konplik dalam Pilkada.

d. Penghitungan Suara dan Penetapan Pemenang Pilkada

Dalam tahap ini juga tidak kalah rawannya, diaman dalam proses ini juga sering kali menjadi penyebab terjadinya konflik massa yang berujung perusakan dan lain-lain. Bahkan berdasarkan Pilkada yang pernah terlaksana sebelumnya, klaim berkaitan dengan proses penghitungan dan penetapan pemenang Pilkada menempati porsi terbesar dari semua sengketa antar para peserta Pemilu yang sering menyebabkan konflik di berbagai daerah. ${ }^{28}$

Berdasarkan pasal 107 ayat 1 UU 32 tahun 2004, pasangan calon kepala daerah dan wakil yang memperoleh suara lebih dari 50 persen dari jumlah suara sah ditetapkan sebagai pasangan calon terpilih, artinya jika ada yang mencapai suara dengan jumlah lebih dari 50 persen maka dia menjadi pemenang dan tidak perlu putaran kedua. Lalu ayat 2, apabila ketentuan sebagaimana dimaksud pada ayat 1 tidak terpenuhi, maka pasangan calon yang memperoleh suara lebih dari 25 persen dari jumlah suara sah dinyatakan sebagai pemenang dan berhak mengikuti putaran kedua. Selanjutnya ayat 3, dalam hal pasangan calon yang memperoleh suara tersebar-sebagaimana dimaksud pada ayat 2-terdapat lebih dari satu pasang calon yang perolehan suaranya sama,

27Lihat Agus Rie wanto, Ensiklopedi Pemilu, Analisis Kritis Intropektif Pemilu2004 Menuju Agenda Pemilu2009, h. 231.

${ }^{28}$ Lihat Donni Edwin, et al, Pilkada Langsung Demokratisasi Daerah dan Mitos Good Gavernance, h. 86 . 
penentuan pasangan calon terpilih dilakukan berdasarkan kepada wilayah perolehan suara yang lebih luas. ${ }^{29}$

Ayat 3 tersebut biasanya merupakan sumber potensi konflik amuk massa, kareana menimbulkan problematik. Alasannya, ketentuan dalam ayat 3 tersebut penjelasannya tidak diatur secara tegas dalam PP 6/2005. Konflik itu biasanya dimulai dari gugatan publik, dengan mempertanyakan apa yang dimaksud dengan wilayah perolehan suara yang lebih luas dan bagaimana prosedur penghitungannya. Andai problem ini tidak terjawab melalui regulasi yang tepat, atau hanya diserahkan kepada KPUD saja, maka amat mungkin berpotensi menyulut konflik. Apalagi, tradisi publik di negeri ini, yang belum terbiasa menerima kekalahan secaraarif dan bijaksana.

\section{Model Konflik yang Diakibatkan Oleh Situasi dan Karakteristik Politik Lokal}

Kemungkinan terjadinya konflik dalam penyelenggaraan Pilkada bukan semata-mata disebabkan oleh buruknya aturan main, tetapi juga berasal dari situasi dan karakteristik politik lokal. Situasi dan karakteristik politik antara satu daerah dengan daerah lain yang berbeda, membedakan pula potensi konfliknya. Wilayah-wilayah yang tergolong daerah konflik, seperti Maluku, Ambon, Poso, Aceh, Mamasa dan Sulawesi tentu lebih rawan terjadinya konflik dibandingkan dengan daerah lainnya. Sehingga hal itu pasti membutuhkan cara dan penanganan khusus dalam penanganannya.

${ }^{29}$ Lihat Agus Rie wanto, Ensiklopedi Pemilu, Analisis Kritis Intropektif Pemilu2004 Menuju Agenda Pemilu2009, h. 231. 
Tetapi diatas semua itu, aturan main yang tidak bersih dan adil memperbesar probablitas terjadinya konflik di semua daerah. ${ }^{30}$

Kendati terdapat beberapa perbedaan, ada beberapa pola konflik menyangkut pemilihan umum yang berlaku di hampir semua daerah di Indonesia. Pertama, konflik antar kelompok pendukung. Pola ini tampak sudah menjadi seperti kebiasaan seharihari tidak hanya dalam pemilihan umum, melainkan juga dalam peristiwa-peristiwa lain. Dan dalam banyak kasus, muncul pula pengelompokan massa pendukung dengan kecendrungan fanatik terhadap kelompoknya sekaligus mempersiapkan kelompok lain sebagai kelompok luar. Pada situasi demikian, uang, solidaritas dan sentimen suku, marga, etnis, agama atau kedaerahan, misalnya isu putra daerah, biasanya juga menjadi pemicu konflik. ${ }^{31}$

Selain digerakkan dan terjadi konflik oleh faktor di atas mobilisasi massa pendukung oleh para elit setempat, juga didorong oleh loyalitas primordial bahkan kekeluargaan (keluarga besar). Sejauh mata rantai jaringan patron-klien, kawula-gusti, tuan-hamba belum putus dari panorama politik Indonesia, maka konflik pendukung tetap menjadi bahaya laten dalam setiap penyelenggaraan pemilihan umum.

Kemudian, pola konflik kedua adalah konflik antar elit politik yang akhirnya menyeret pertikaian antar massaa pendukung.Secara umum, pengaruh elit dalam politik Indonesia sangat besar mengingat lemahnya masyarakat sipil kareana berbagai macam faktor penyebab. Dalam konteks Pilkada, elit politik mencakup para kandidat, elit partai atau elit politik lainnya baik pada tataran lokal

${ }^{30}$ Lihat Donni Edwin, et al, Pilkada Langsung Demokratisasi Daerah dan Mitos Good Gavernance,, h. 87.

${ }^{31}$ LihatLe o Agustino, Pilkada dan Dinamika Politik Lokal, h. 150. 
maupun pusat, memiliki kepentingan masing-masing atas hasil Pilkada. ${ }^{32}$

Salah satu fenomena elit yang menonjol pasca reformasi adalah menguatnya peran dari apa yang akhir-akhir dikenal dengan istilah raja kecil di tingkat lokal. Banyak kasus konflik di daerah pasca rezim Soeharto menunjukkan indikasi yang kuat telah dipicu oleh perebutan sumber daya lokal diantara para elit lokal atau nasional. Para raja kecil dicirikan oleh kemampuan ekonomi, memiliki jaringan dengan elit nasional, serta memelihara kelompok -kelompok paramiliter atau satuan tugas, termasuk kelompok kekersan. ${ }^{33}$

Sehingga, motivasi para raja kecil dalam di tingkat lokal untuk mempengaruhi proses Pilkada amat kuat mengingat sumber daya ekonomi mereka biasanya tergantung pada proyek pemerintah atau bisnis ilegal yang membutuhkan perlindungan politik, dan ini biasanya juga menyebabkan konflik di tingkat grass root.

Pola konflik ketiga, yaitu konflik yang melibatkan satuan tugas (satgas) partai politik dan preman terorganisir. Sebagaimana kita ketahui, hampir semua partai besar memiliki satgasnya masingmasing atau berafiliasi dengannya. Gejala ini sudah muncul di beberapa daerah, saat massa pendukung calon memperotes keputusan KPUD karena calon tidak memenuhi persyaratan administratif yang ditentukan UU. ${ }^{34}$ Maka, premanisme politik dan pemaksaan kehendak bisa muncul pula dengan cara-cara kekerasan. Dan ironisnya kadang banyak yang memakai jasa preman yang terorganisir untuk melakukan hal tersebut.

${ }^{32}$ Lihat Donni Edwin, et al, Pilkada Langsung Demokratisasi Daerah dan Mitos Good Gavernance,,h. 89.

${ }^{33}$ Lihat Donni Edwin, et al, Pilkada Langsung Demokratisasi Daerah dan Mitos Good Gavernance,,h. 89.

${ }^{34}$ LihatLe o Agustino, Pilkada dan Dinamika Politik Lokal, h. 151. 


\section{Fenomena Elit Lokal (daerah): Tinjauan Terhadap Pilkada NTB}

Kebijakan politik desentralisasi melalui otonomi daerah pascaOrde Baru telah membawa implikasi terhadap adanya pergeseran lokus politik ke daerah-daerah, adalah munculnya kekhawatiran akan semakin kuatnya fragmentasi masyarakat politik di daerah berdasarkan kriteria-kriteria lokal. ${ }^{35}$ Kekhawatiran ini tentu menjadi beralasan ketika hampir semua daerah di Indonesia ditandai dengan struktur masyarakat yang majemuk yang berpotensi bagi munculnya sentimen-sentimen komunal dalam kehidupan politik lokal. Sentimen lokal yang sangat kuat dapat mengarah pada munculnya konflik horizontal yang bersifat primordial. Dalam bentuk yang lebih konkret, konflik primordial ini dapat berupa diskriminasi terhadap kelompok primordial yang jumlahnya lebih sedikit bahkan dapat juga mengarah pada berkembangnya etnosentrisme atau semangat kedaerahan yang berlebihan.

Kasus-kasus pemilihan kepala daerah mengungkapkan semakin meluasnya penggunaan istilah putra daerah sebagai parameter etnisitas yang seringkali tidak diimbangi dengan pertimbangan profesionalisme dan prinsip persamaan hak bagi setiap komponen masyarakat lokal untuk berkompetisi dalam rekrutmen politik maupun rekrutmen birokrasi. Tapi dalam satu sisi banyaknya putra daerah yang ingin maju menjadi kepala daerah dan berkuasa, juga menjadi fenomena tersendiri dalam kasus kepala daerah apalagi didalamnya nanti akan terjadi kontestasi dan persaingan politik. ${ }^{36}$ Demikian pula, tuntutan untuk melakukan pemekaran wilayah atau pembentukan propinsi/kabupaten/kota

${ }^{35}$ LihatTim Lapera. Otonomi Pemberian Negara : Kajian Kritis atas Kebijakan Otonomi Daerah, (Yogyakarta: Lapera Pustaka Utama, 2000), h. xxi.

36 LihatCaroline Paskarina dan Dede Mariana, Demokrasi dan Politik Desentralisasi, h. 110. 
yang baru dapat menggambarkan fenomena kebangkitan etnisitas sekaligus perebutan penguasaan sumber-sumber daya alam tertentu, seperti kelautan, tambang, dan kehutanan, dan sebagainya. Berbagai kecenderungan inilah yang mengarah pada potensi munculnya konflik etnis-politis yang mengakar dan sulit terselesaikan. Secara empirik, telah ditunjukkan bahwa seringkali konflik etnis-politis dipicu oleh masalah identitas yang berdempetan dengan masalah distribusi sosial maupun ekonomi yang tidakmerata.

Perkembangan dan realitas diatas lalu kemudian melahirkan elit yang berasal dari partai politik dan masyarakat. Muncul dan lahirnya kelompok elit dalam masyarakat biasanya dihubungkan dengan dua pandangan. Pandangan pertama menyatakan bahwa kemunculan kelompok elit bukan merupakan proses alamiah. Melainkan mereka adalah orang-orang terpilih, yang dikaruniai kelebihan oleh tuhan, kemampuan dan keahlian lebih yang lebih besar yang memungkinkan mereka mampu memecahkan dan mengatasi persoalan-persoalan kehidupan dan mereka memiliki potensi pribadi yang lebih besar daripada yang lain dan yang termasuk kelompok elit dalam hal ini adalah kiyai atau tokoh agama lainnya. Pendapat kedua menyatakan bahwa kemunculan kelompok elit merupakan hasil dari kompleksitas organisasi-organisasi sosial, terutama yang berkaitan dengan tantangan ekonomi dan politik yang heterogen. ${ }^{37}$ Mereka terpilih untuk menempati posisi-posisi kunci dalam organisasi dan punya wewenang untuk menjalankan organisasi, terutama dalam merencanakan, mengatur, memotivasi, dan mengontrol kegiatan-kegiatan, dan yang termasuk kelompok elit dalam hal ini biasanya ketua organisasi kemasyarakatan, ketua partai poitik, pejabat pemerintah dan publik dan lain-lain.

37 Pe ndapat ini dapat dilihat dalam bukunya Yusron, Elit Lokal dan Civil Society, (Jakarta: LP3ES, 2009), h. 69. 
Lebih spesifik lagi dalam partai-partai politik, elit ini biasanya berasal dari kalangan yang bergerak dilingkungan pengusaha, purna wirawan TNI/POLRI, pengsiunan birokrasi, aktivis LSM, dan bahkan dari lingkungan pendidikan umum dan agama. ${ }^{38}$ Dan husus dalam lingkungan pendidikan agama yang sering kali kiyai ikut terjun dan terseret arus dalam aktifitas politik praktis yang kemudian mau tidak mau menuntutnya memakai bahasa agama dalam aktifitas politiknya. Ini seringkali terjadi dalam masyarak Indonesia karena dengan pertimbangan Indonesia merupakan negara yang mayoritas berpendudk muslim. sehingga agama merupakan komoditas menarik untuk dijadikan materi dalam kampanye dengan tujuan untuk melegitimasi sikap dan perilaku partainya untuk kepentingan politik. ${ }^{39}$ Dalam kaitan ini lantas terjadi semacam desekralisasi agama sehingga agama pada gilirannya, kehilangan maknanya yang paling esensial dan sakral.

Muncul dan hadirnya elit ini telah menjadi faktor penggerak, terutama berkaitan dengan pemberdayaan politik masyarakat (political empowerment of society). Lepas dari upaya mereka untuk mendapatkan keuntungan politik, elit di tingkat lokal telah mewarnai kembali tradisi bersaing di kalangan masyarakat dalam mendapatkan sumber-sumber ekonomi dan bahkan kekuasaan, yang kadang tidak sedikit berakhir dengan konflik di tataran elit dan bahkan di kalangan pendukung atau masyarakat bawah (grassroot).

Fenomena dan model problematika elit di atas juga terjadi terhadap elit lokal di daerah NTB. Lahir dan munculnya elit-elit lokal di NTB memiliki tipologi yang sama seperti yang di bahas di

${ }^{38}$ Lihat Endang Turmudi et. al, Yang Pusat dan Yang Lokal Antara Dominasi, Resistensi, dan Akomodasi Politik di Tingkat Lokal, (Yogyakarta: Pustaka Pelajar, 2004), h. 150.

39 Lihat Faisal Ismail, NU Gusdurisme dan Politik Kiyai, (Yogyakarta: Tiara Wacana Yogya, 1999), h. 129. 
atas, banyak diantara mereka dilahirkan dari organisasi masa dan aktivis lainnya. Sehingga dalam Pilkada langsung Gubernur NTB pada tahun 2008 kemarin banyak diwarnai oleh persaingan dan perpecahan elit. Jika berkaca terhadap pikada NTB tahun 2008 yang diikuti oleh empat pasangan paket calon kepala daerah, maka persis setelah Pilkada dilangsung dan setelah pemenang ditetapkan, hampir tidak ada pasangan calon lain yang keberatan dengan hasil yang diperoleh oleh masing-masing pasang calon. Dalam Pilkada NTB yang pertama kali dipilih langsung oleh rakyat itu berhasil megeluarakan pasangan DR. TGKH. Zainul Majdi dan Badrul Munir, MM sebagai pemenang tunggal dengan perolehan suara lebih dari 60 persen suara sah dan meninggalkan jauh perolehan suara calon-calon lain yang rata-rata memperoleh suara di bawah 30 persen. ${ }^{40}$ Ini artinya dalam Pilkada NTB tersebut berhasil dilakukan dalam sekali putaran, karena pasangan DR. TGKH. Zainul Madjdi dan Badrul Munir, MM dapat ditetapkan langsung sebagai pemenang karena berhasil meraih suara sah lebih dari 60 persen.

Keluarnya pasangan DR. TGKH. Zainul Majdi dan Badrul Munir, MM sebagai pemenang dalam Pilkada NTB, dapat meciptakan suasana dan kondisi yang relatif aman dan tidak menimbulkan konflik pasca ditetapkan dan dilantik sebagai Gubernur NTB terpilih periode 2008-2013. Ini tetu pemandangan yang kontras jika melihat fenomena politik lokal di beberapa daerah Indonesia yang lain, dimana sering kali permasalahan Pilkada selalu menjadi penyebab timbulnya masalah yang berakhir dengan pertikaian. Namun pemandangan itu tidak terjadi dalam Pilkada NTB, karena para pasangan calon yang kalah sangat legawa dan berbesar hati menerima kekalahannya. Sehingga tidak ada gugatan

${ }^{40}$ Lihat Laporan KPU NTB Tahun 2008 Tentang Hasil Pemilihan Calon Gubernur. 
keberatan dan protes terhadap kemengan pasangan DR. TGKH. Zainul Majdi dan Badrul Munir, MM. Ini tentu menjadi poin penting yang menciptakan suasana aman dan terkendali pasca Pilkada, karena dengan kebesaran hati para calon yang kalah berarti juga para konstituen pendukung calon yang kalah ikut legawa menerima kekalahannya, dan persis tidak menimbulkan konflik dan pertikaian di kalangan masyarakat bawah (grassroot).

Kemenangan DR. TGKH ${ }^{41}$. Zainul Majdi yang juga disebut Tuan Guru Bajang ini juga relatif bisa diterima karena memang status dia yang juga merupakan ulama besar di NTB dan merupakan pimpinan organisasi terbesar di NTB yakni Nahdlatul Wathan $(\mathrm{NW})^{42}$. Sehingga sangat wajar dan masuk akal jika dia mampu meraup suara sah sampai 60 persenan karena dia memiliki jamaah dan santri yang cukup banyak sebagai konstituennya, dan disamping itu juga dia memiliki kharismatik serta modal sosial yang memadai. Selain itu, kemenangan DR. TGKH. Zainul Majdi sebagai Gubernur NTB lebih didominasi oleh faktor figur dibanding dengan mesin politik. Artinya bahwa tidak ada korelasi jumlah suara partai

41 Merupakan singkatan dari Tuan Guru Kiyai Haji (T.G.K.H). Dalam persefektif masyarakat Lombok merupakan ge lar keagamaan yang diberikan ole $\mathrm{h}$ masyarakat ke pada seseorang yang memiliki kapasitas keilmuan dalam bidang agama dan penamaan gelar ini tumbuh dari kalangan masyarakat, dan secara umum sosok yang disebut tuan guru kiyai haji memiliki pesantre $\mathrm{n}$ dan basis masyarakat terte ntu dan pernah me lakukan ibadah haji. Lihat Asnawi, Agama dan Paradigma Sosial Masyarakat: Menykapi Pemahaman Masyarakat Sasak Tentang Taqdir Allah dan Kematian Bayi, (Jakarta: Centra Media, 2006), cet. 1., h. 23. Lihat juga Zamakhsyari Dhofier, Tradisi Pesantren: Studi Tentang Pandangan Hidup Kyai, (Jakarta: LP3ES, 2011), cet. 8. h. 93

${ }^{42}$ Merupakan organisasi yang bergerak dalam bidang pe ndidikan, sosial dan dakwah yang Didirikan ole h TGKH Muhammad Zainuddin Abdul Madjid pada tanggal 1 Maret 1953 M, yang berkedudukan berpusat di Pancor Lombok Timur, Nusa Te nggara Barat, Indonesia. Lihat Muh. Noer, dkk, Visi Kebangsaan Religius: Refleksi Pemikiran dan Perjuangan TGKH Muhammad Zaenuddin Abdul Madjid 19041997, (Jakarta: Logos Wacana Ilmu, 2004), cet. 1., h. 211. 
politik yang mendukung pada Pilkada dengan jumlah suara yang diraih oleh partai. Dengan ke-ulama-annya mampu meraih suara mayoritas dengan mengalahkan calon dari partai-partai lainnya. ${ }^{43}$ Ini juga sangat masuk akal jika melihat model masyarakat yang sangat patronase, artinya masih melihat faktor figus sebagai faktor penting dalam mengambil keputusan.

Namun dibalik capaian itu terdapat sedikit konflik internal dalam tubuh NW itu sendiri, diman pada awalnya sebelum Pilkada dilangsungkan memang sudah terjadi perpecahan menjadi dua kubu. Tepatnya ketika TGKH. M. Zainuddin abdul madjid wafat pada tahun 1997 yang selaku pendiri NW, sebuah konflik mencuat diantara kedua putrinya-Siti Rauhun dan Siti Raehanun-yang memperebutkan siapa yang menggantikannya, baik sebagai ketua NW maupun sebagai pemain inti dalam dinamika politik. ${ }^{44}$ Akibatnya, masing-masing mempunyai keinginan untuk menguasai NW sebagai organisasi Islam terbesar di NTB. Maka pada tanggal 2426 Juli 1998, digelar Muktamar X NW di Peraya Lombok Tengah NTB, dan terpilihlah Siti Raehanun dan Hayyi Nu'man masing- masing sebagai Ketua Umum dan Sekertaris Jenderal periode 1998- 2003. Pendukung Siti Rauhun menganggap hasil tersebut tidak sah dan melanggar Anggaran Dasar NW yang menjunjung tinggi mazhab Imam Syafi'i, salah satu fatwanya melanggar perempuan jadi pemimpin. ${ }^{45}$

${ }^{43}$ Lihat Daud Gerung, et.al, Lombok Mirah Sasak Adi, Sejarah Sosial, Ekonomi, dan Politik, (Jakarta: Imsak Press, 2011), h. 227.

${ }^{44}$ He nk Schulte Northolt, et al., (ed), Renegotiating Boundaries; Local Politicks in Post-Suharto Indonesia,Politik Lokal di Indonesia, terjemahan Bernard Hidayat (Jakarta: Yayasan Obor Indonesia, 2009), h. 380.

${ }^{45}$ Masnun, TGKH Muhammad Zainuddin Abdul Madjid: Gagasan Pembaruan di Nusa Tenggara Barat, cet. 1., h. 241. 
Atas ketidak puasan hasil muktamar NW X tersebut, selanjutnya pada tanggal 11 Desember 1998 pendukung Rauhun menggelar muktamar yang disebut muktamar reformasi. Dalam muktamar tersebut TGKH. Zainul Majdi, anak kandung Siti Rauhun terpilih menjadi Ketua Umum dan TGH. Abdul Hanan sebagai Sekertaris Jenderal PBNW periode 1998-2003. ${ }^{46}$ Pasca muktamar reformasi, organisasi NW mengalami dualisme kepemimpinan dan masing-masing kelompok merasa sah sebagai pengurus PBNW. Konflik dualisme kepemimpinan di tubuh NW tersebut secara otomatis juga merubah peta perpolitikan NW itu sendiri, masingmasing kubu memilih jalan politik sendiri. Sehingga dalam Pilkada NTB 2008 lalu-pun dua kubu itu mendukung dan mengusung calon yang berbeda, dimana kubu Siti Rauhun mengusung anaknya sendiri DR. TGKH. Zainul Majdi sebagai calon yang kemudian keluar menjadi pemenang dan kubu Siti Raehanun mengusung incumben waktu itu Drs. Lalu Srinata tapi ternyata kalah.

Pasca Pilkada permasalahan ini tentu masih membekas dan berimplikasi terhadap elit NW itu sendiri, sehingga perselisihan di antara elit NW itu sendiri tidak bisa dihindari walaupun tidak sampai terlalu membawa pengaruh di tingkat bawah. Ini terbutkti dari suasana aman dan terkendali pasca Pilkada dan tidak sampai menimbulkan kerusuahan maupun peperangan. Jadi perpecahan elit itu hanya terjadi dalam tataran elitnya itu sendiri. Dan inilah bentuk konflik yang terjadi dalam Pilkada NTB yang perlu penyelesaian.

${ }^{46}$ Masnun, TGKH Muhammad Zainuddin Abdul Madjid: Gagasan Pembaruan di Nusa Tenggara Barat, cet. 1., h. 242. 


\section{Memperkuat Peran Good Governance dan Civil Society Sebagai Model Resolusi Konflik Dalam PilkadaNTB}

Dalam konteks sosial-politik lokal dan global yang ditandai dengan pergeseran ke arah liberalisme politik dan ekonomi membawa konsekuensi pada pergeseran model pemerintahan yang semakin mempersempit peran negara dan pemerintah. Pendekatan desentralisasi yang dianut dalam UU No. 22 Tahun 1999 berada dalam kerangka model pemerintahan good governance. Model pemerintahan ini tidak menempatkan pemerintah sebagai aktor tunggal dalam penyelenggaraan pemerintahan tapi juga harus melibatkan para stake holder lainnya, seperti civil society ${ }^{47}$ dan elit politik. Sinergi antara para aktor ini lah yang akan mewujudkan tata kepemerintahan yang baik (good governance). 48

Akan tetapi, pemaknaan good governance sebenarnya tidak hanya mencakup suatu model pemerintahan tapi juga sebagai suatu model manajemen konflik. Pendekatan ini mensyaratkan agar dalam mengelola konflik, pemerintah daerah atau nasional harus memiliki konsensus mengenai norma-norma pengelolaan konflik institusi

${ }^{47}$ Civil Society pertama kali diperkenalkan ole h Adam Ferguson, pemikir dari Scoklandia. Sejak itu civil socie ty selalu diperbincangkan dalam diskursus politik saat masyarakat mengalami perubahan sosial dan untuk mencapai hubungan yang ideal antara negara dan masyarakat. Lihat Yusron, Elit Lokal dan Civil Society, (Jakarta: LP3ES, 2009), h. 16. Dan jika melihat dari sekian banyak de finisi te ntang Civil Socie ty dalam literatur-lite ratur yang telah ditulis, minimal dapat ditarik benang emas, bahwa yang dimaksud de ngan Civil Socie ty adalah sebuah kelompok atau tatanan masyarakat yang berdiri secara mandiri di hadapan pe nguasa dan negara, memiliki ruang publik (publicspare) dalam mengemukakan pe ndapat, adanya lembaga-le mbaga yang mandiri yang dapat me nyalurkan aspirasi dan kepe ntingan publik dan dalam Bahasa Indonesia cendrung diterjemahkan de ngan istilah MasyarakatMadani. Lihat Tim Pe nyusun PUSLIT IAIN Syarif Hidayatullah Jakarta, Pendidikan Kewargaan, Demokrasi, HAM dan Masyarakat Madani, (Jakarta: IAIN Press, 2000), h. 139.

48 LihatCaroline Paskarina dan Dede Mariana, Demokrasi dan Politik Desentralisasi, h. 119. 
atau lembaga yang legitimit dan sumber-sumber daya yang mendukung. Upaya untuk melakukan ketiga hal inilah yang dikerangkai dalam model good governance, yakni dengan melibatkan pihak-pihak yang berkonflik. Untuk menyelesaikan konflik, ada istilah resolusi konflik. Resolusi konflik dapat diartikan sebagai usaha menyelesaikan konflik dengan cara-cara analitis dan masuk ke akar permasalahan. Resolusi konflik dijalankan untuk memberikan penyelesaian yang dapat diterima. ${ }^{49}$

Model good governance dan civil society sebagai resolusi konflik memungkinkan institusi-institusi lokal ntuk turut berperan dalam penyelesaian konflik dengan cara ikut mengakomodir dan diajak bergabung. Sehingga dapat meminimalisir terjadinya konflik karena nanti didalamnya terdapat rasa toleransi dan menghargi perbedaan yang cukup tinggi yang pada akhirnya dapat menjadikan suasana lebih kondusip. Dan pada akhirnya, menghormati aspek -aspek lokal kedaerahan dan mengakomodasi kepentingan-kepentingan daerah dalam manajemen pembangunan yang desentralistis dan pengelolaan mesin politik atas dasar konsepsi good governance dan civil society merupakan suatu alternatif resolusi konflik etnis dalam kerangka otonomi daerah.

\section{Penutup}

Dari sekian bahasan di atas minimal dapat disimpulkan beberapa poin penting diantaranya adalah. Pertama, dengan diberlakukannya UU No. 32 Tahun 2004 merupakan tonggak awal dimasa reformasi yang memberikan kedaulatan penuh terhadap rakyat di daerah, sehingga rakyat di daerah berhak memilih secara langsung kepala daerah yang dikehendaki tanpa diwakili lagi oleh

${ }^{49}$ Lihat Ihsan Darmawan, Bentuk Resolusi Konflik Dalam Pilkada, Dalam Jurnal Politika, Vol 1, No. 1, April 2010. h. 40. 
DPRD. Kedua, Pilkada daerah bukan merupakan sekedar aktifitas politik untuk memilih kepala daerah semata melainkan lebih kepada pembaruan kontrak sosial sebagai pengikat dalam membangun komitmen pemerintah terpilih dengan rakyat dimasa pemerintahannya, sehingga terjadi check and balancing yang seimbang antara keduanya. Ketiga, walaupun Pilkada langsung merupakan bentuk kemajuan demokratisasi di Indonesia akan tetapi terkadang tidak sedikit menimbulkan konflik di daerah yang berujung pertikaian dan perpecahan dan pada akhirnya ikut merubah tatanan sosial yang sudah ada, sehingga Pilkada memerlukan cara dan proses yang lebih terbuka, jujur dan transparan dalam pelaksanaannya demi mencapai cita-cita luhur dari pikada itu sendiri. Dan keempat, terciptanya good governance dan civil society bisa menjadi solusi atas berbagai konflik yang terjadi di daerah pasca Pilkada, sehingga good governance dan civil society mutlak di laksanakan oleh pemerintah daerah guna menciptakan kedamaian dan ketentraman di daerah. [w]

\section{Daftar Pustaka}

Agustino, Leo, Pilkada dan Dinamika Politik Lokal, (Yogyakarta:

Pustaka Pelajar, 2009).

Asnawi, Agama dan Paradigma Sosial Masyarakat: Menykapi Pemahaman Masyarakat Sasak Tentang Taqdir Allah dan Kematian Bayi, (Jakarta: Centra Media, 2006).

Chalid, Pheni et al, Pilkada Langsung Demokratisasi Daerah dan Mitos Good Gavernance, (Jakarta: Pusat Kajian Ilmu Politik UI Bekerjasama Dengan Partnership Kemitraan, 2005).

Chumaidi, Chozin H.A, Etika Politik dan Esensi Demokrasi, Jejak

Pemikiran Demokratisasi Politik Indonesia, (Jakarta: Pustaka Indonesia Satu, 2006). 
Dhofier, Zamakhsyari, Tradisi Pesantren: Studi Tentang Pandangan Hidup Kyai, (Jakarta: LP3ES, 2011).

Darmawan, Ihsan, Bentuk Resolusi Konflik Dalam Pilkada, Dalam Jurnal Politika, Vol 1, No. 1, April2010.

Gerung, Daud, et.al, Lombok Mirah Sasak Adi, Sejarah Sosial, Ekonomi, dan Politik, (Jakarta: Imsak Press, 2011).

Hidayat, Komaruddin, Politik Panjat Pinang, Dimanakah Peran Agama, (Jakarta: Penerbit Buku Kompas, 2006).

Henk Schulte Northolt, et al., (ed), Renegotiating Boundaries; Local Politicks in Post-Suharto Indonesia,Politik Lokal di Indonesia, terjemahan Bernard Hidayat (Jakarta: Yayasan Obor Indonesia, 2009).

Ismail, Faisal, NU Gusdurisme dan Politik Kiyai, (Yogyakarta: Tiara Wacana Yogya, 1999).

Paskarina, Caroline dan Dede Mariana, Demokrasi dan Politik Desentralisasi, (Yogyakarta: Graha Ilmu, 2008).

Dede Mariana dan Caroline Paskarina, Dede Mariana Demokrasi dan Politik Desentralisasi, (Bandung: Puslit KP2W Lemlit UNPAD, 2007).

Muh. Noer, dkk, Visi Kebangsaan Religius: Refleksi Pemikiran dan Perjuangan TGKH Muhammad Zaenuddin Abdul Madjid 19041997, (Jakarta: Logos Wacana Ilmu, 2004), cet. 1.

Partanto, A Pius dan Dahlan al Barry, Kamus Ilmiah Populer, (Surabaya: Penerbit Arloka, 1994).

Riewanto, Agus, Ensiklopedi Pemilu, Analisis Kritis Intropektif Pemilu2004 Menuju Agenda Pemilu2009, (Yogyakarta: el-SAB bekerjasama dengan Fajar Pustaka, 2007).

Sarundajang, S.H, Pilkada Langsung Problematika Dan Prospek, (Jakarta: Kata Hasta Pustaka, 2005).

Tim Lapera. Otonomi Pemberian Negara : Kajian Kritis atas Kebijakan Otonomi Daerah, (Yogyakarta: Lapera Pustaka Utama, 2000).

Tim Penyusun PUSLIT IAIN Syarif Hidayatullah Jakarta, Pendidikan Copyright (C) 2018 Politea: Jurnal Kajian Politik Is lam 
Kewargaan , Demokrasi, HAM dan Masyarakat Madani, (Jakarta: IAIN Press, 2000).

Turmudi, Endang et. al, Yang Pusat dan Yang Lokal Antara Dominasi, Resistensi, dan Akomodasi Politik di Tingkat Lokal, (yogyakarta: pustaka pelajar, 2004).

Kamus Besar Bahasa Indonesia, (Jakarta: Pusat Bahasa Depdiknas, 2008).

Urbaningrum, Anas, Ranjau-ranjau Reformasi; Potret Konflik Politik Pasca Kejatuhan Soeharto, (Jakarta: PT RajaGrafindo Persada, 1999).

Yusron, Elit Lokal dan Civil Society, (Jakarta: LP3ES, 2009). 